\title{
Contribucións para o estudo da rede de igrexarios como base dunha organización territorial sustentable
}

\author{
Contributions to the study of the "igrexarios" network as basis for a \\ sustainable territorial organisation \\ FERNANDO MINGOTE RODRÍGUEZ \\ orcid.org/0000-0001-7868-1916 \\ fernando.mingote@gmail.com \\ PLÁCIDO LIZANCOS MORA \\ Universidade da Coruña \\ orcid.org/0000-0003-3823-6054 \\ placido.lizancos@udc.es e
}

\section{RESUME}

En amplas zonas de poboamento espallado no noroeste da Península Ibérica, as parroquias non son tanto unha división eclesiástica como unha entidade social e xeográfica. Dentro dos seus límites, os igrexarios (isto é; o conxunto formado pola igrexa, cemiterio, carballeira, cruceiros e casa reitoral; polo común na veciñanza dunha pequena aldea) constitúen o seu cerne. Nesta zona, os igrexarios forman unha malla sobre a paisaxe cultural e representan os fitos de súa identidade. A maior parte aséntanse nos seus lugares desde a Idade Media, e evidencian conexións cun pasado máis remoto. Con frecuencia inclúen importantes mostras de arquitectura histórica, así como de espazos de gran calidade ambiental.

Nesta investigación analizamos 750 parroquias rurais e os seus igrexarios que constitúen unha área de máis de 6200 quilómetros cadrados do noroeste galego, diagnosticando o seu estado mediante o sistema DAFO, e propoñendo estratexias para a súa conservación e a renovación das súas funcións. Palabras chave: Galicia, parroquias, paisaxe cultural, análise territorial.

\section{Abstract}

In vast areas of scattered population in the NW of Galicia, parishes are less an ecclesiastic division, than a social and geographical item. Within their limits, "igrexarios", (that's to say; the set of: church, graveyard, public grove, stone crosses used as landmarks, and priest house; in the common case close to a hamlet) constitute the core of them. In this area, igrexarios form a network on the cultural landscape and they represent the landmarks of its identity. Most of them were settled during the Middle Age and show traces of even earlier precedents. They often include important pieces of historical architecture, and environmental quality spaces. 
In this research we analyse 750 rural parishes and their igrexarios, which constitute a more than 6200 square kilometres area in the NW of Galicia, detecting their condition by using the SWOT system, and proposing strategies for their conservation and the renewal of their functions.

Keywords: Galicia, church yards, cultural landscape, territorial analysis.

\section{INTRODUCIÓN}

O traballo que presentamos deriva da tese ${ }^{1}$ de doutoramento en arquitectura, presentada ante o departamento de Representación e Teoría Arquitectónica da Universidade da Coruña, A rede de igrexarios e a identidade do territorio: os conxuntos vinculados ao patrimonio arquitectónico parroquial no medio rural do noroeste galego. O estudo é a un tempo unha investigación territorial e un diagnóstico cultural, desde a perspectiva dos seus autores, arquitectos de profesión.

A investigación apoiase no coñecemento dos igrexarios, auténticos nodos sociais que se foron construíndo en paralelo á rede parroquial, entendida esta non tanto como unha mera división eclesiástica, se non como unha entidade social e xeográfica que articula o territorio rural. Dentro dos límites da parroquia, os igrexarios (isto é; o conxunto formado pola igrexa, cemiterio, carballeira, cruceiros e casa reitoral; polo común na veciñanza dunha pequena aldea) constitúen o seu cerne. Na zona obxecto de estudo, os igrexarios forman unha malla sobre a paisaxe cultural e representan os fitos de súa identidade. A maior parte aséntanse nos seus lugares desde a Idade Media e evidencian conexións cun pasado máis remoto. Con frecuencia inclúen importantes mostras de arquitectura histórica, así como de espazos de gran calidade ambiental.

Nesta investigación analizamos 750 parroquias rurais e os seus igrexarios, que constitúen unha área de máis de 6200 quilómetros cadrados, do noroeste galego, diagnosticando o seu estado mediante o sistema DAFO, e propoñendo estratexias para a súa conservación e a renovación das súas funcións.

Partindo da hipótese da incesante transformación do hábitat rural, quérese diagnosticar o estado actual do territorio desde a comprensión das funcións que desempeñan hoxe estes elementos, de cara a propoñer as estratexias necesarias para continuar a construción do territorio e de acordo cos estándares actuais do desenvolvemento sustentable. Chegado o caso, definiranse os criterios metodolóxicos que deberían guiar esas formas de construción.

$\mathrm{O}$ estudo esténdese a un ámbito continuo que comprende as comarcas costeiras dende Ortegal a Muros (Ferrol, A Coruña, Bergantiños, Soneira, Fisterra e Xallas), internándose polo interior até Eume, Betanzos, Terra de Melide, Arzúa, Ordes e Santiago. O número de parroquias estudadas representa o $90 \%$ das da provincia da Coruña. A elección do ámbito de estudo pretende representar a maior variedade dentro das diferentes formas

1 Use this link to cite

http://hdl.handle.net/2183/16201 
de ocupación do territorio. Preténdese así mesmo que este se estenda sobre os elementos que se atopan dentro do ámbito rural, aínda sabendo as dificultades que definir ese termo ten, xa que como é ben sabido os fenómenos rurais e urbanos en Galicia están fortemente mesturados, e non é doado saber onde comeza un e remata o outro, como explicou o urbanista e profesor Juan Luis Dalda (2006) a través do concepto de Cidade Difusa.

\section{METODOLOXÍA ANALÍTICA}

Para facer este estudo, analizamos as características tipolóxicas, o grao de conservación e a relación coa estrutura territorial de certos conxuntos de bens inmobles do patrimonio cultural, cos seus espazos públicos vinculados, que conforman os igrexarios das correspondentes parroquias obxecto do estudo. Fíxose para elo unha recolleita de datos de inmobles inventariados nas normativas estatal, autonómica e municipal, así como os existentes nos arquivos da Dirección Xeral do Patrimonio Cultural da Xunta de Galicia, así como outras fontes documentais e bibliografía, que recollen unha gran variedade de material procedente de traballos de campo de diferentes fontes; convenios coas Universidades, co Colexio de Arquitectos e con outros colectivos, presentando un acervo de varios miles de elementos en centos de pezas documentais. Despois dunha primeira selección e clasificación, todos os inmobles foron visitados fisicamente, avaliados e fotografados, entre os anos 2003 e 2011. Aparte dos que figuraban nas bases de datos, moitos outros foron atopados e incorporados. Todos eles foron xeolocalizados e clasificados tipoloxicamente. Por último analizáronse as configuracións dos seus elementos e a súa contorna, mediante visualización das súas fotografías aéreas, facéndose clasificacións e estudos tipolóxicos dos mesmos sobre o conxunto dos 750 estudados.

O proceso comeza pola identificación dos bens (igrexas, cruceiros, casas reitorais, etc.) e a súa agrupación como partes dos mesmos igrexarios. A continuación analizaremos:

- se o igrexario se atopa illado, na contorna dun núcleo rural ou no seu interior,

- se se atopa na contorna dun castro e a que distancia do mesmo;

- se existen todos os elementos dun igrexario completo ou non;

- se existen satélites do igrexario a xeito de capelas, ermidas ou campos de romaría ou non.

No canto a cada un dos elementos, polo miúdo analizaremos se a igrexa se atopa nun adro pechado ou non, e a tipoloxía deste adro, como é a tipoloxía da planta; se está orientada coa cabeceira ó leste ou non, se se atopa en uso ou abandonada, etc.; se existe cruceiro ou non, e se este está no igrexario ou dentro do adro da igrexa; como é a reitoral e se está en uso, abandonada ou en ruína.

Trala identificación da posición dos igrexarios, o seguinte fito da investigación será a súa adscrición a áreas territoriais onde se dan condicións de homoxeneidade. Isto suponse que facilitará a elaboración de propostas de intervención. Nesta labor a maiores da mera 
observación dos elementos e a comparación das súas características, teremos en conta o grao de urbanización das parroquias (definido polo Instituto Galego de Estatística) ${ }^{2}$, a caracterización paisaxística na que se insiren e a extensión física das mesmas, que tamén ven condicionada polas características físicas do territorio en que se asentan.

Basearemos esta análise no estudo en gabinete de todos os mapas que se achegaron ao estudo destes fenómenos; concretamente:

- Os mapas das formas do solo agrícola de Abel Bouhier. Un traballo que sintetiza a monumental obra do xeógrafo francés que é a gran referencia na cartografía das configuracións tradicionais do solo agrario en Galicia, fundamentadas nas agras e socalcos e as súas variedades (Bouhier 1979).

- O Mapa dos Usos Potenciais da Terra en Galicia, unha perspectiva arqueolóxica, de Brais Currás Refojos (2014). Este investigador elaborou un mapa de usos potenciais da terra desde o enfoque da arqueoloxía da paisaxe. Terá en conta para o mesmo diferentes aspectos como as calidades estruturais da terra (pendente, afloramentos, profundidade, risco de erosión), o réxime hídrico ou a dispoñibilidade de nutrientes.

- O mapa de Grandes Áreas Paisaxísticas de Galicia elaborado polo Instituto de Estudos do Territorio da Xunta de Galicia. ${ }^{3}$

- O mapa das Comarcas de Galicia elaborado pola Sociedade Anónima de Desenvolvemento Comarcal de Galicia, dentro do ambicioso proxecto de articulación territorial de Galicia levado a cabo durante quince anos entre 1990 e 2005, e que finalmente non chegou a termo.

- O mapa parroquial discriminando no mesmo grupos homoxéneos pola extensión física das parroquias (menores de $5 \mathrm{~km}^{2}$, entre 5 e $10 \mathrm{~km}^{2}$, entre 10 e $20 \mathrm{~km}^{2}$ e maiores de $20 \mathrm{~km}^{2}$ ) Hai que ter en conta que polo xeral a extensión física das parroquias é consecuencia directa da proporción de solo apto para usos agrarios que conteñen e esta pola súa banda da súa configuración xeográfica.

Non se esquece neste estudo a consideración de grandes tensións alleas ao mundo rural, como é a presenza ou proximidade das áreas urbanas no Golfo Ártabro e nas Terras de Santiago, dos procesos de despoboamento nas Serras Centrais e de Ortegal ou paso do Camiño Francés polas Terras de Melide e Arzúa, do Camiño de Fisterra pola área homónima.

Sobre os mapas referidos elabóranse un conxunto de mapas interpretativos superpostos ó mapa parroquial no conxunto das parroquias estudadas:

a) Mapa de Estrutura do Solo Agrario, feito interpretando o de Abel Bouhier, coa configuración tradicional do solo agrario predominante na parroquia.

2 Clasificación das parroquias segundo o grao e subgrao de urbanización. http://www.ige.eu/estatico/pdfs/ s3/clasificacions/urbanizacion/MetodoloxiaGU2016eAnexo_Modificada.pdf

3 Mapa de Grandes Áreas Paisaxísticas de Galicia elaborado polo Instituto de Estudos do Territorio da Xunta de Galicia de conformidade coa lei 7/2008, de 7 de xullo, de protección da paisaxe de Galicia. 
b) Mapa dos Usos Potenciais da Terra, interpretando o plano de Brais Currás; Mapa dos Usos Potenciais da Terra en Galicia, unha perspectiva arqueolóxica, sobre o conxunto de parroquias estudadas, asignando o uso potencial predominante na parroquia.

c) Mapa das Grandes Áreas Paisaxísticas do Instituto de Estudos do Territorio sobre o conxunto de parroquias estudadas.

d) Mapa indicativo da extensión das parroquias, considerando que a extensión das mesmas tamén está directamente relacionado coas súas características físicas.

De todos estes datos e a lectura destes mapas de elaboración propia obtense unha división en dez áreas que se consideran axeitadas para o estudo dos igrexarios e que de norte a sur e de oeste a leste serán as seguintes:

1. Ortegal.

2. Golfo Ártabro.

3. Serras Centrais.

4. Agras occidentais bergantiñáns.

5. Zona de Transición.

6. Fisterra-Soneira.

7. Agras do Interior.

8. Xallas-Ría de Muros.

9. Terras de Santiago.

10. Terras de Arzúa e Melide.

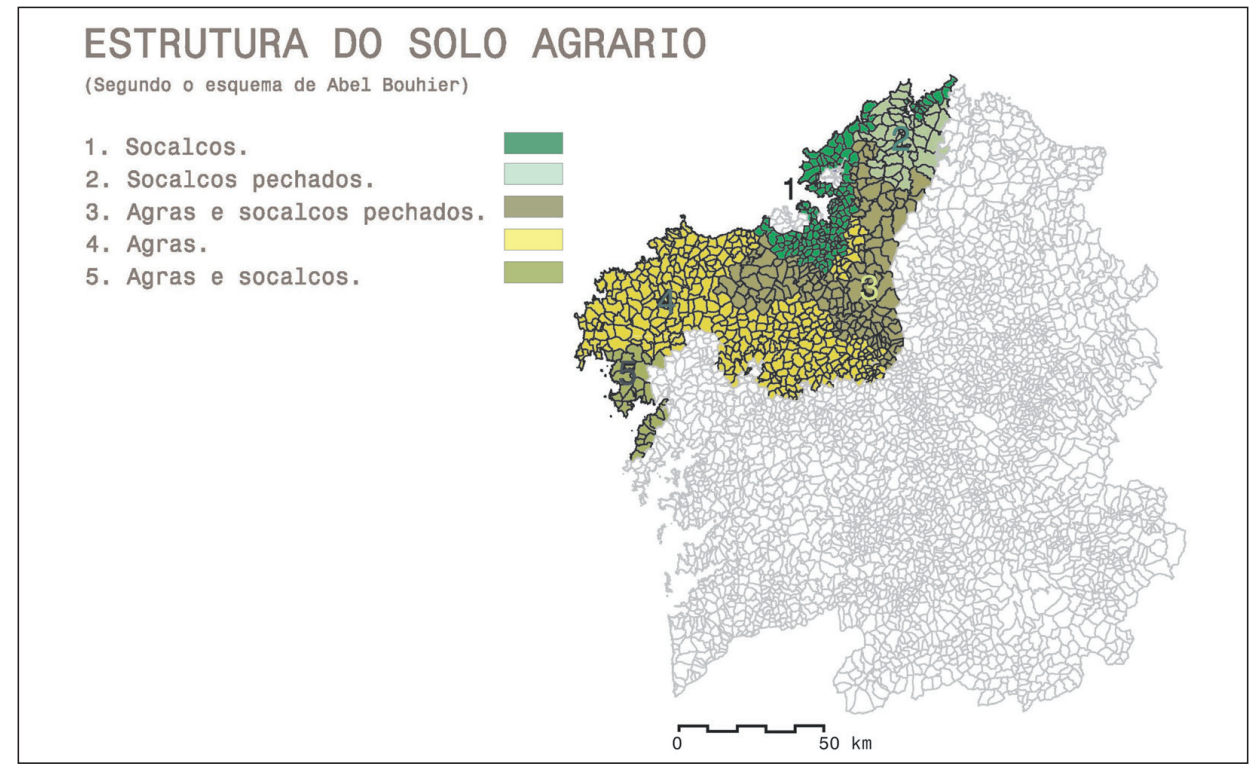

Elaboración propia sobre o mapa de parroquias interpretando o mapa de Abel Bouhier (1979). 


\section{USOS POTENCIAIS DA TERRA}

(Interpretación sobre o mapa parroquial do plano de Brais Currás. Uso predominante na parroquia)

1. Intensiva.

2. Extensiva.

3. Mixta.

4. Potencial nulo.

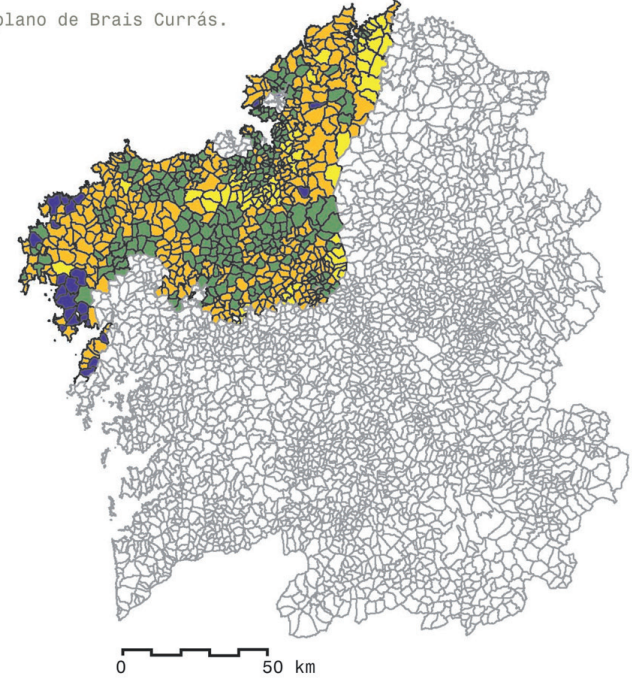

Elaboración propia interpretando o mapa de Brais Currás (2014).

\section{ÁREAS PAISAXÍSTICAS}

(Segundo o Instituto de Estudos do Territorio)

1. Galicia Setentrional.

2. Golfo Ártabro.

3. Chairas e fosas occidentais.

4. Rías Baixas.

5. Galicia Central

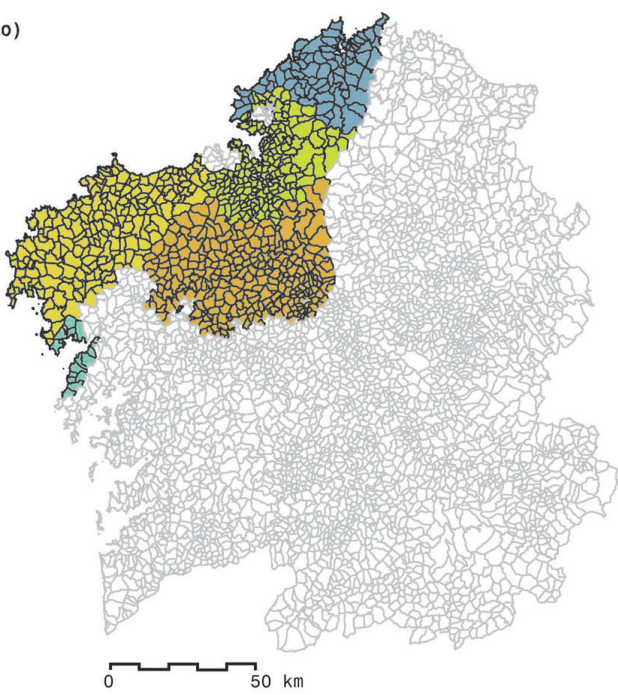




\section{TAMAÑO das PARROQUIAS}
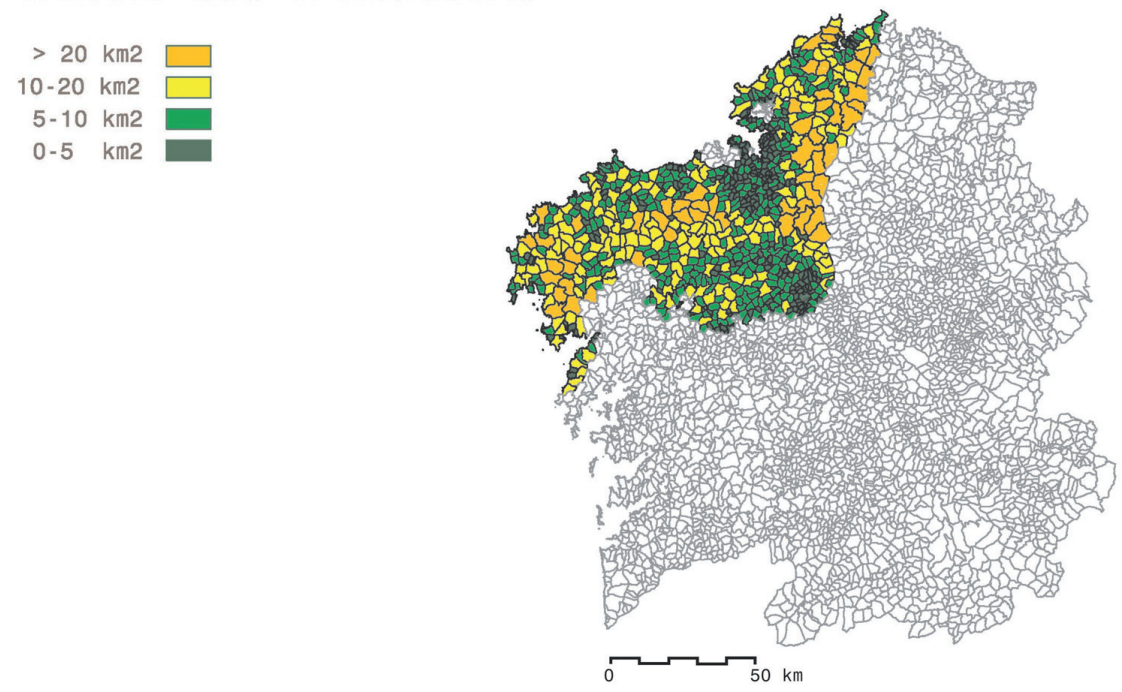

AREAS de ESTUDO dos IGREXARIOS
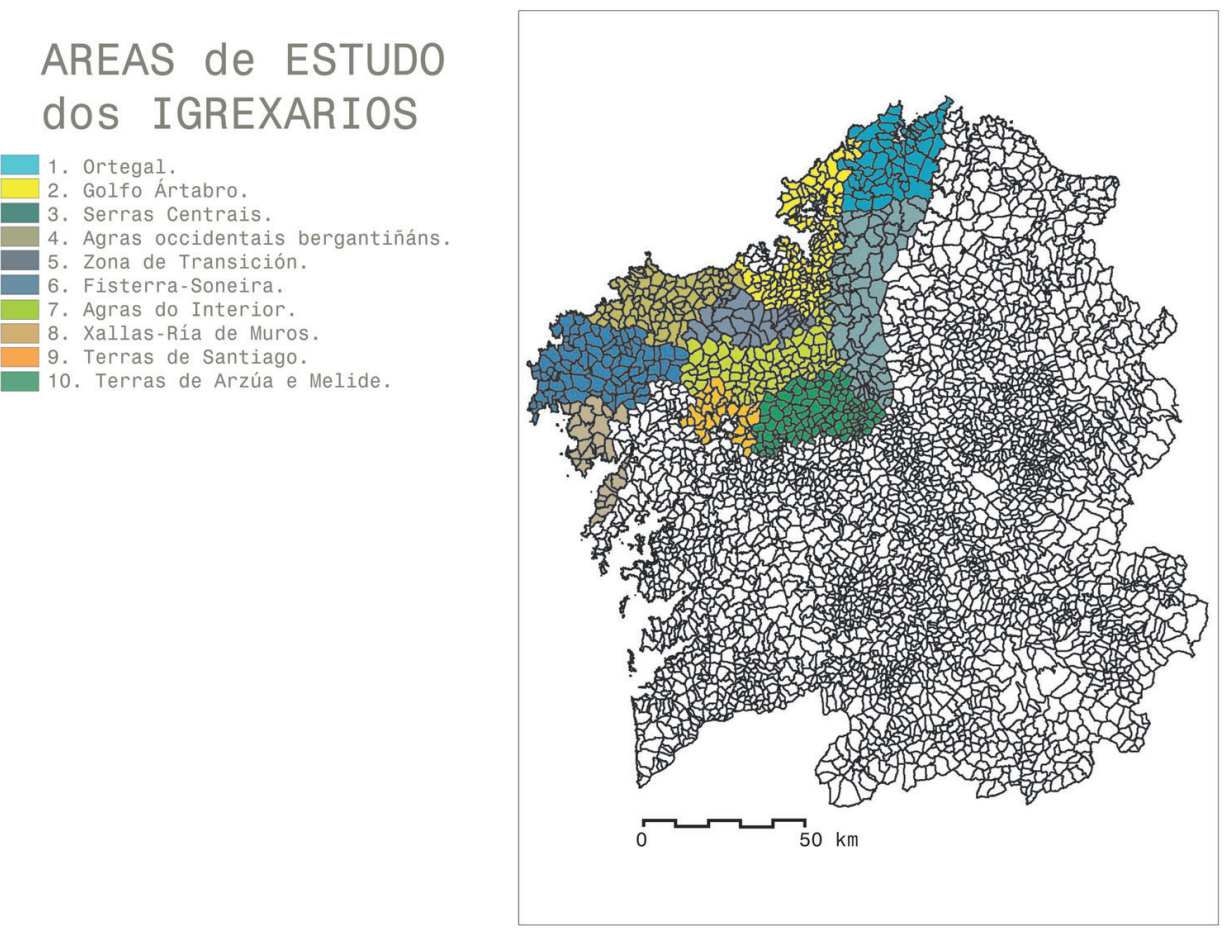
De cada un dos setecentos cincuenta igrexarios estudaranse os seguintes elementos, resumidos nunha ficha dun catálogo:

a) Identificación

Nome da Parroquia

Área xeográfica na que se asenta a parroquia

Grao de urbanización da parroquia segundo o Instituto Galego de Estatística

Extensión da parroquia

b) A igrexa

Estilo arquitectónico da igrexa parroquial

Estado do uso da igrexa

Orientación da súa cabeceira

Tipoloxía da planta da igrexa

c) $\mathrm{O}$ adro como elemento territorial

Planta do Adro

Relación do igrexario co núcleo máis próximo

Orientación do igrexario respecto ó núcleo

d) Outros elementos do igrexario

Cruceiro: presenza ou non é situación no igrexario

Reitoral existencia ou non e o seu estado

Carballeira da igrexa

Existencia ou non de castro e distancia do mesmo á igrexa

Presenza ou non de outras ermidas na parroquia

Nunha última fase da investigación escolleuse unha mostra de igrexarios que se considera representativa de cada unha das zonas homoxéneas (18 exemplos). Sobre cada un destes igrexarios así seleccionados realizouse un estudo máis pormenorizado, que inclúe unha representación gráfica interpretativa do conxunto dos elementos que conforman o igrexario dentro da parroquia (entendido este como un organismo), das tensións que lles deron orixe e das que están a producirse na actualidade. Estúdanse as debilidades, fortalezas, ameazas e oportunidades de cada unha delas e propóñense por último unha serie de propostas de actuación.

\section{MARCO FÍSICO E CULTURAL PARA O ESTUDO DOS IGREXARIOS}

\subsection{Contexto histórico}

Son moitos os que ven a orixe das parroquias galegas nos antigos castros. De feito a distribución destes sobre a paisaxe galega vai parella á distribución das parroquias. Esta correspondencia xa foi advertida por primeira vez por Alberto Sampaio (1895) para o ámbito do norte de Portugal. 
O castro foi a célula organizativa da estrutura social galega na edade antiga, como apunta Felipe Arias (1992, pp. 35-32) na súa obra A romanización en Galicia, cada individuo pertencería a un populus que funcionarían a xeito de estado (con todas as salvedades propias do caso) e dentro deste a un castellum ou castro, con territorio propio. Os núcleos situábanse polo xeral sobre pequenos outeiros con situación estratéxica a pouca distancia de concas capaces de acoller unha agricultura de subsistencia e preto tamén das zonas boscosas. Entre o baixo imperio e a alta idade media os castros son abandoados e a poboación dos mesmos pasa a ocupar o espazo circundante dun xeito máis disperso. Nesta época aparecen as chamadas villae medievais e con elas as primeiras estruturas parroquiais propiamente ditas. José Carlos Sánchez Pardo (2007, pp. 103-134) explica ben este proceso. María del Carmen Pallares (1978) por outra banda estuda o caso concreto da villae medieval "villa Bidualdo" no actual concello de Santiso.

As primeiras fontes documentais da estrutura parroquial galega proceden do parroquial suevo ou división de Teodomiro, documento do século VI que describe a organización administrativa eclesiástica do reino suevo e no que se relacionan as 13 dioceses existentes na época en Gallaecia (Viseu, Dumio, Egitania, Lugo, Ourense, Astorga, Iria, Tui e Britonia) e as parroquias e pagi pertencentes ás mesmas, ata un total de 120 núcleos de poboación.

$\mathrm{O}$ que semella claro é que as bases da estrutura territorial das parroquias, tal e como hoxe as coñecemos xa estaban completamente conformadas no século XII. James D'Emilio (1996) suxire que a maior parte das igrexas parroquiais xa eran vellas nestas datas e que en moitos casos, a configuración dos seus territorios recordaba a organización de asentamentos dun tempo aínda anterior. Esta estrutura vaise asentando desde esta época ata a actualidade, sen grandes cambios nun xeito de organización bastante espontáneo. A mediados do século XIX, o Estado asume maiores competencias no sustento da rede parroquial e a cambio esixe unha reestruturación da mesma. En 1867 o arcebispado de Santiago fixo unha reordenación parroquial, suprimindo algunhas e creando outras. O sistema baseábase no francés de organización territorial e dábanse certos criterios para esta nova distribución (Barreiro, 2009). En realidade, a pesares do grande esforzo de sistematización, a operación supuxo ben poucos cambios, seguramente porque a estrutura existente xa se correspondía cun modelo bastante racional.

En 1883 as parroquias foron agrupadas en concellos e foi escollida unha capital municipal. Pero esta agrupación foi en xeral bastante artificial e os vínculos de pertenza da veciñanza aínda quedarían ligados á parroquia.

\subsection{O marco físico}

O igrexario forma un conxunto que aglutina os equipamentos tradicionais da parroquia. Os seus elementos serven a todo o seu conxunto e existe unha dobre influenza; o seu emprazamento ven condicionado pola estrutura agraria da parroquia na que se asenta e ó mesmo tempo, este inflúe na configuración física da mesma.

O modelo que pode explicar a configuración física da maior parte das parroquias na área estudada é o de unha paisaxe cóncava sobre a que se superpoñen varias mallas que 
representan os diferentes tipos de aproveitamento do solo, o esquema dos asentamentos humanos e unha estrutura viaria que os relaciona. Veremos que importancia terá a localización do igrexario neste conxunto.

A organización dos usos do solo dentro da parroquia busca o maior aproveitamento de cada un dos seus sectores para o desenvolvemento da economía agraria de autoconsumo que orixinou a súa morfoloxía. Unha explicación superficial da estrutura do solo en Galicia pode referirnos ó problema do minifundismo e como este pode levar a unha estrutura anárquica ou caprichosa do solo e os seus usos, con cada propietario coa súa leira, a súa horta, os seus prados, etc. Pero esta é unha explicación moi simplista da estrutura do agro galego. En realidade, cada aldea funciona como una entidade colectiva de propiedade, onde en moitas ocasións se comparten uns montes (os montes veciñais), uns medios industriais rudimentarios (o muíño), e un campo de cultivo (a agra). A agra posúe na maior parte dos casos un valado único, uns accesos únicos e se posúe colectivamente con cotas de participación que son as leiras, estas si pertencentes a cada individuo e delimitadas por uns simples marcos. Esta distribución ten a súa orixe na fundación das vilas medievais e perpetuaríase ata o século XIX, nun réxime de propiedade onde os campesiños eran maiormente arrendatarios das terras. Patrick O'Flanagan suxire que a aldea representa unha serie de propiedades manexadas en conxunto (O'Flanagan 1995, p.40), pero que constitúen posesións independentes. Fainos tamén un diagrama explicativo dos usos do solo na parroquia de Salto, en Vimianzo, baseado á súa vez nun de Jesús García Fernández (1975). Nel pódense ver os asentamentos situados a medio camiño entre o monte (por riba) e as terras de cultivo (por baixo) e un pouco máis aló os pastos. As terras de cultivo están agrupadas en agras.

Parroquia de Salto. Interpretación propia do esquema de Jesús García Fernández (1975) que inclúe O’Flanagan na súa Xeografia Histórica de Galicia. Laranxa: aldeas e barrios cos elementos menores de terreo. Verde claro: labradío. Verde escuro: terreo de monte. Verde-amarelo: prados. Ocre: monte bravo.

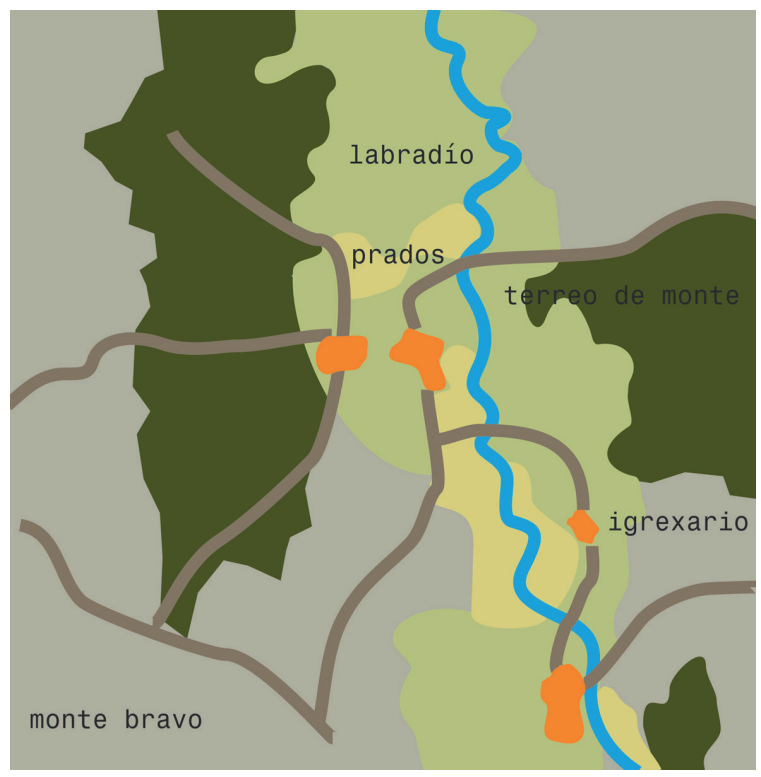




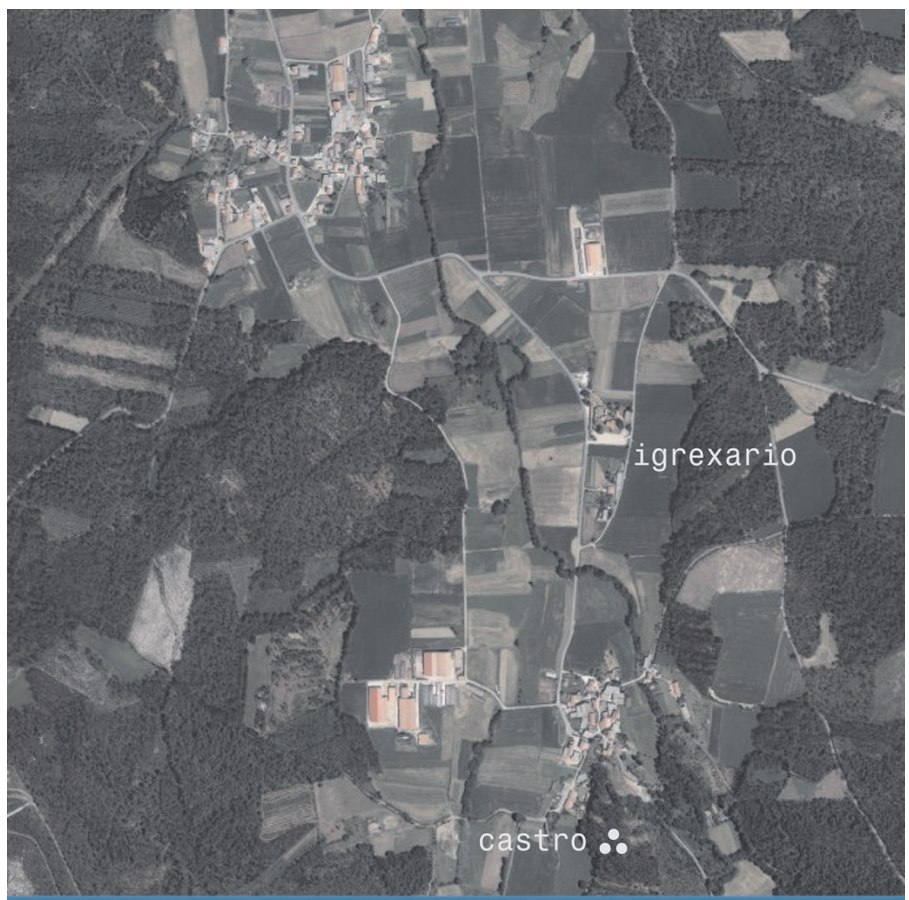

Vista aérea da zona representada da parroquia de Salto (2014).

A media ladeira aséntanse as edificacións. A cotas máis baixas, pero preto delas esténdense as terras de labor, polo xeral terreos drenados e soleados, as máis das veces en contornas delimitadas formando as agras. En cota máis baixa, onde as terras se anegan con frecuencia, se atopan os pastos para o gando, a carón das ribeiras dos ríos e regatos. No curso o muíño, moitas veces comunal da parroquia, aporta a elemental tecnoloxía. Por riba das vivendas se atopan as zonas de bosque (monte alto), que se utilizan para subministro da madeira, castañas, etc. Máis arriba aínda atópase o monte baixo, que tamén se utiliza como pasto extensivo, nun modelo que pódenos facer recordar o concepto da "sección do val" de Patrick Geddes ${ }^{4}$ (1854-1932).

Paula Ballesteros vai máis aló do diagrama bidimensional de Patrick Geddes e define esta paisaxe cultural como "a paisaxe cóncava" (Ballesteros 2002).

Segundo este modelo, cada unha das "unidades xeomorfolóxicas mínimas significativas" que acollen unha unidade social produtiva do sistema agrario tradicional, pódense sintetizar coa figura gráfica dunha paisaxe cóncava, na que se asentan os diferentes usos precisos. Así aparecen as células elementais que son quen de sustentar a precaria economía dunha ducia de casas e que están na orixe das actuais parroquias.

4 Geddes, P., (1923) The Valley Section From Hills to Sea. New York. 
Sobre os límites xeográficos da parroquia aséntanse polo xeral diferentes núcleos de diverso tamaño e configuración. O número medio de asentamentos por parroquia é duns oito.

O igrexario atópase no caso máis común na contorna dun núcleo (Tabla I). O núcleo que acolle ó igrexario non ten porqué ser de maior tamaño da contorna, nen tampouco presentar características que o fagan ser diferente por algunha singularidade respecto dos outros que compoñen a parroquia. En todo caso, o que si se verifica e que de preferencia se trata de entidades que teñen unha posición de centralidade. Porén, a presenza da igrexa ${ }^{5}$ caracteriza ó núcleo, e así o reflicte o propio nomenclátor da Xunta de Galicia, onde se recollen os topónimos "A Igrexa" ou os seus derivados como "Eirixe”, "Eirexa", "Grixa”, etc. O feito de conter o igrexario fai tamén que os precarios espazos e equipamentos públicos tradicionais se asenten polo común nas súas inmediacións.

Precedo Ledo propón un esquema da parroquia elemental. Os asentamentos xunto coas súas agras agrúpanse nun modelo de simetría radial, co centro parroquial no seu centro. De modo teórico, o castro orixinario do poboamento podería atoparse preto deste centro parroquial.

Estrutura espacial da parroquia. Elaboración propia a partires dun esquema de Precedo Ledo (1998).

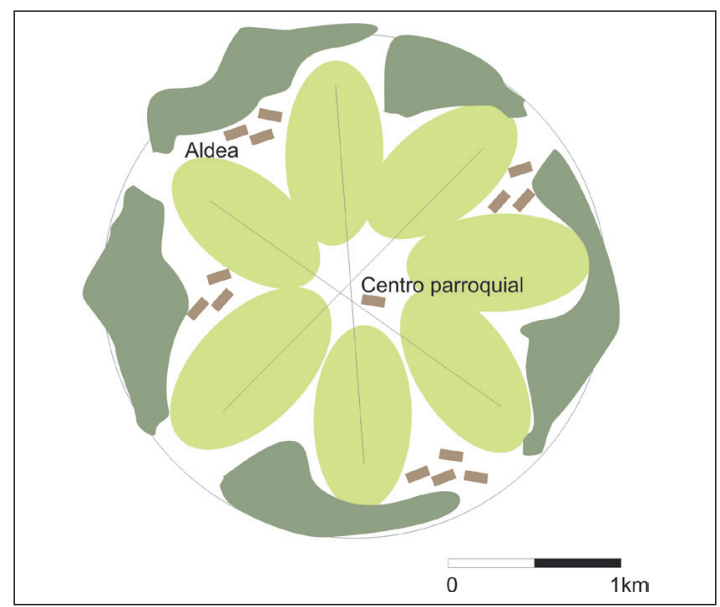

\section{ELEMENTOS DO IGREXARIO}

A partir da investigación realizada chegamos á conclusión de que a relación dos elementos que conforman o igrexario tradicional completo ${ }^{6}$ estaría composta por:

5 Segundo os nosos datos, dun total de 514 núcleos que conteñen a igrexa na súa contorna ou no seu interior, sobre un total de 750 parroquias estudadas atopamos topónimos que se refiren ó igrexario en 217 (o $42 \%$ do total).

6 A escola, normalmente de data moi posterior ó resto dos elementos, moitas veces encóntrase tamén no igrexario. 
1. A igrexa parroquial, dentro do seu adro.

2. $\mathrm{O}$ adro, que contén o cemiterio e a casa de la fábrica.

3. O camposanto ou cemiterio.

4. Os cruceiros.

5. A carballeira ou campo da festa.

6. A casa reitoral.

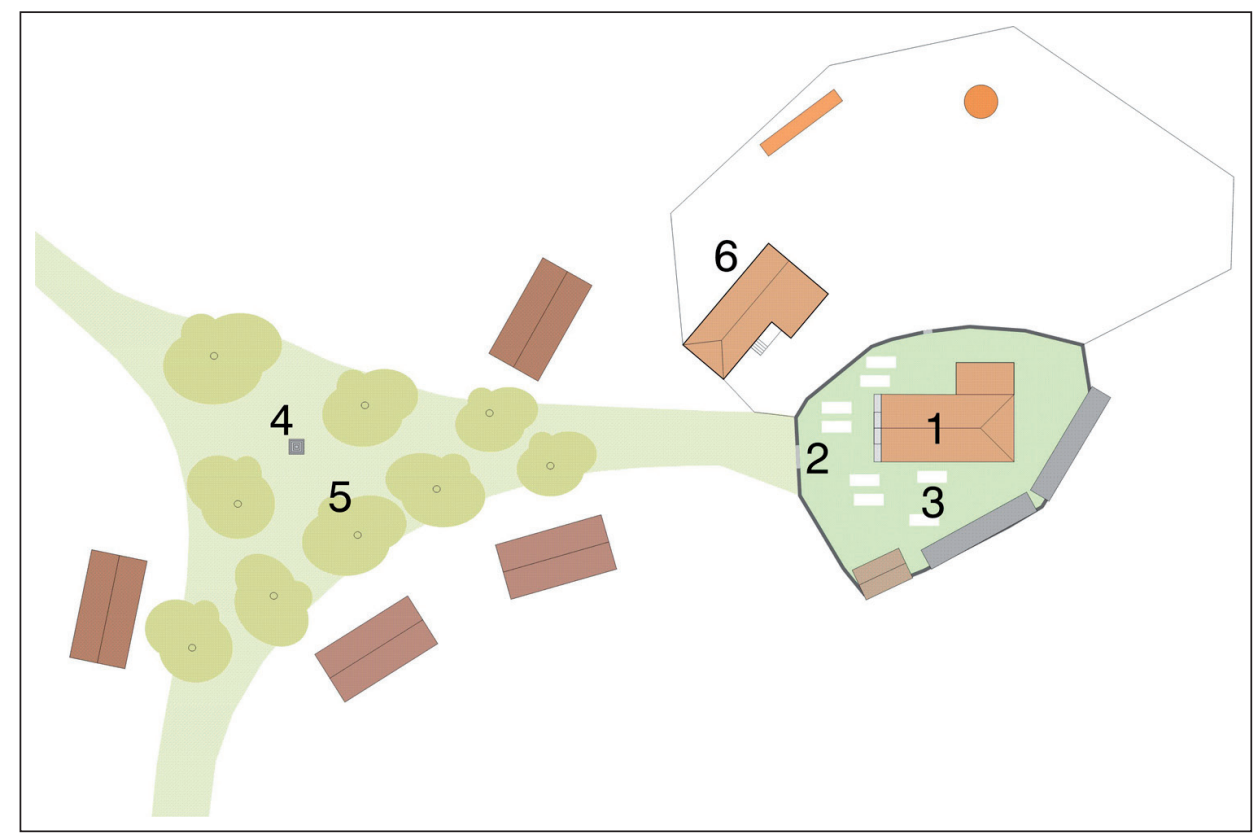

A presenza da totalidade dos elementos non é nin moito menos maioritaria no conxunto dos igrexarios estudiado, se non que tan só se dá no $20 \%$ dos casos $(19,76 \%)$ Sen embargo, si existe na práctica totalidade dos casos o número mínimo de elementos para recoñecer perfectamente o igrexario como un organismo conxunto.

Despois da análise do estado actual das 750 parroquias do ámbito de referencia resulta esta imaxe global:

Táboa. Compoñentes do igrexario

\begin{tabular}{|lll|}
\hline Compoñente & Número absoluto & Porcentaxe sobre o total \\
\hline Adro & 719 & $95,99 \%$ \\
\hline Reitoral & 377 & $50,67 \%$ \\
\hline Cruceiro & 559 & $75,13 \%$ \\
\hline Carballeira do igrexario & 365 & $48,73 \%$ \\
\hline
\end{tabular}


Dos 750 casos recollidos, hai 148 nos que atopamos a totalidade dos elementos do igrexario, independentemente do seu estado (un $20 \%$ do total).

Tamén dos 148, hai 51 nos que se pode atopar un castro nas súas proximidades. Destes 148 casos, hai 49 que teñen una ermida satélite.

Discriminando por zonas obtemos o seguinte cadro referido á presenza dos diferentes elementos do igrexario:

Táboa. Compoñentes do igrexario. Porcentaxes segundo área xeográfica

\begin{tabular}{|l|c|c|c|c|c|c|c|c|c|c|}
\hline & \multicolumn{10}{|c|}{ Áreas } \\
\cline { 2 - 24 } & OR & AR & SR & TR & BG & FT & IN & AZ & MR & ST \\
\hline Adro & 84 & 97 & 97 & 100 & 98 & 93 & 98 & 96 & 96 & 100 \\
\hline Reitoral & 68 & 45 & 37 & 43 & 46 & 56 & 55 & 50 & 68 & 64 \\
\hline Cruceiro & 51 & 58 & 78 & 84 & 89 & 91 & 84 & 74 & 75 & 76 \\
\hline Carballeira & 44 & 41 & 52 & 41 & 32 & 45 & 67 & 57 & 25 & 82 \\
\hline Todos os elementos & 21 & 9 & 10 & 22 & 13 & 27 & 30 & 23 & 14 & 45 \\
\hline
\end{tabular}

Táboa. Relación do igrexario co núcleo máis próximo. Porcentaxe por áreas xeográficas

\begin{tabular}{|l|c|c|c|c|c|c|c|c|c|c|c|c|}
\hline & Número & xeral & OR & AR & SR & TR & BG & FT & IN & AZ & MR & ST \\
\hline Externo a núcleo & 229 & 31 & 33 & 44 & 29 & 38 & 23 & 17 & 35 & 29 & 18 & 27 \\
\hline No interior dun núcleo & 154 & 20 & 18 & 19 & 22 & 8 & 30 & 23 & 14 & 17 & 18 & 33 \\
\hline Na contorna dun núcleo & 367 & 49 & 49 & 37 & 49 & 54 & 48 & 60 & 51 & 54 & 64 & 40 \\
\hline Total & 750 & & & & & & & & & & & \\
\hline
\end{tabular}

Táboa. Existencia de ermidas de romaría nas parroquias

\begin{tabular}{|l|c|c|c|c|c|c|c|c|c|c|c|c|}
\hline & $\begin{array}{c}\text { Número } \\
\text { absoluto }\end{array}$ & xeral & OR & AR & SR & TR & BG & FT & IN & AZ & MR & ST \\
\hline $\begin{array}{l}\text { Ermida na mesma } \\
\text { parroquia }\end{array}$ & 255 & 34 & 53 & 25 & 32 & 38 & 33 & 32 & 35 & 30 & 46 & 48 \\
\hline
\end{tabular}

Táboa. Evidencia de castro na parroquia e á distancia do mesmo ó cemiterio parroquial

\begin{tabular}{|l|c|c|c|c|c|c|c|c|c|c|c|c|}
\hline & Núm. & xeral & OR & AR & SR & TR & BG & FT & IN & AZ & MR & ST \\
\hline Castro localizado & 302 & 40 & 30 & 51 & 36 & 24 & 43 & 31 & 43 & 46 & 11 & 58 \\
\hline $\begin{array}{l}\text { Distancia media igrexa - } \\
\text { castro (metros) }\end{array}$ & 658 & 559 & 733 & 668 & 623 & 743 & 642 & 531 & 575 & 883 & 767 \\
\hline
\end{tabular}

Táboa. Evidencia de reitoral nas parroquias e estado de uso e conservación

\begin{tabular}{|l|c|c|c|c|c|c|c|c|c|c|c|c|}
\hline & Número & xeral & OR & AR & SR & TR & BG & FT & IN & AZ & MR & ST \\
\hline Existencia reitoral & 380 & 51 & 68 & 45 & 37 & 43 & 46 & 56 & 55 & 50 & 68 & 64 \\
\hline Abandonada & 83 & 22 & 26 & 24 & 21 & 19 & 15 & 18 & 26 & 27 & 11 & 19 \\
\hline En ruinas & 75 & 20 & 13 & 22 & 32 & 13 & 10 & 22 & 30 & 16 & 16 & 14 \\
\hline $\begin{array}{l}\text { Abandonada + en } \\
\text { ruinas }\end{array}$ & 158 & 42 & 38 & 46 & 54 & 31 & 26 & 41 & 56 & 43 & 26 & 33 \\
\hline
\end{tabular}


A zona onde hai más proporción de igrexarios presentan a totalidade dos elementos que conforman un igrexario - tipo completo é a de Terras de Santiago. Alí esta circunstancia dáse no 45,45 \% dos casos. Séguenlle as Agras do Interior, cun 29,67 \% de igrexarios completos. No extremo oposto atópase o Golfo Ártabro e a zona das Serras Centrais onde tan só un $10 \%$ dos igrexarios teñen a totalidade dos seus elementos $(9,29 \%$ e $10,39 \%$ respectivamente).

\section{A SITUACIÓN ACTUAL DOS IGREXARIOS}

\subsection{Estado de conservación dos elementos do patrimonio}

En xeral, o estado de conservación dos igrexarios dende un punto de vista funcional é moi bo, aínda que a crise demográfica que padece Galicia -que resulta especialmente acusada nas parroquias interiores- puidera propiciar outra situación.

De feito, apenas un escaso $1 \%$ do total das igrexas encontranse en estado de abandono ${ }^{7}$. Sen dúbida, o feito da indisoluble relación entre a igrexa e o cemiterio ten moito que ver con este estado de cousas, por canto a "parroquia dos mortos" parece na actualidade bastante máis poboada - e xa que logo, máis merecente de atención- que "a parroquia dos vivos".

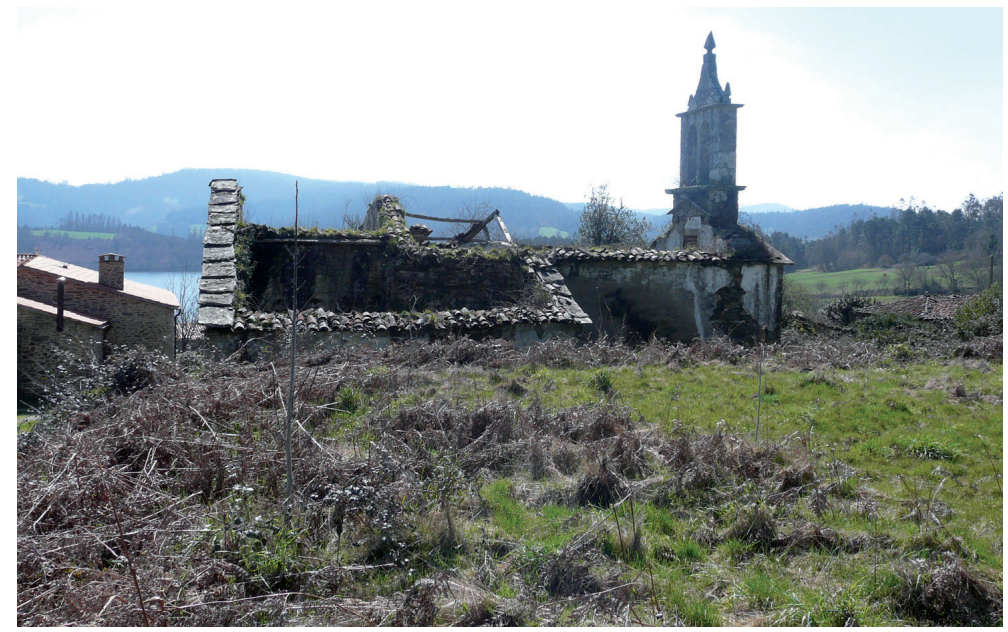

Igrexa en estado de abandono en Viñós, Arzúa.

7 Son sete as igrexas parroquiais abandonadas de entre o total das 750 estudadas: San Pedro de Viñós en Arzúa, San Xián de San Xusto en Coristanco, Santa Baia de Chacín en Mazaricos, San Lourenzo de Doso en Narón, San Salvador do Couzadoiro en Ortigueira, San Xoán do Mosteiro en Ortigueira e San Bartolomeu de Cariño. 


\subsection{Despoboamento e abandono das zonas rurais}

O fenómeno do despoboamento é xeneralizado sobre o conxunto de Galicia, dándose de xeito moito máis acusado nas parroquias rurais. Como din Alberto Pazo Labrador e Pilar Moragón en "Cartografía del despoblamiento en Galicia a escala parroquial. La Galicia Occidental"

A aceleración da urbanización en Galicia, serodia pero moi rápida, ten de positivo o crecemento e a consolidación dun sistema urbano, pero isto faise a costa dunha tamén rápida “desruralización”. Isto explica que a expansión das grandes áreas urbanas de Galicia implique o despoboamento doutras rexións, nas que a estrutura aparente na configuración do territorio se conserva, pero perde os seus contidos.

Este despoboamento, unido ós cambios nos sistemas de produción agraria, fan que moitas terras que levaban sendo cultivadas desde a Idade Antiga sexan abandonadas e pasen a formar parte do que Gilles Clément (2007) denomina "a terceira paisaxe", isto é, zonas que xa non son nin naturais nin humanizadas e, polo tanto, veñen de dar lugar a un ámbito indefinido.

Todos os estudos indican que o fenómeno do despoboamento rural na España Atlántica é imparable, polo que parece que hai que asumilo. Isto nos obriga a coñecer en profundidade os valores dese mundo que desaparece. Só así se poden extraer as conclusións que nos permitan tomar as mellores decisións, de cara a xestionar os seus elementos patrimoniais, o que no seu caso poderá implicar aproveitalas como valor engadido ao territorio transformado.

En palabras de Xosé Carlos Sánchez Pardo:

"No se trata de ser idealistas ni aferrarnos a visiones utópicas del pasado. Estamos ante un lógico e imparable proceso de cambio, al menos a corto y medio plazo. Lo que, como sociedad, debemos hacer de manera urgente pero serena y racional, es afrontar el fundamental debate sobre el despoblamiento rural. Pero debemos hacerlo conociendo y valorando el pasado, no solo por su incalculable valor patrimonial, que es de todos los gallegos, sino también por el conocimiento que de él podemos obtener para comprender las raíces de nuestra organización rural y planificar adecuada y equilibradamente el desarrollo territorial futuro."

8 Si dejamos de mirar el paisaje como si fuese el objeto de una industria podremos descubrir de repente una gran cantidad de espacios indecisos, desprovistos de función, a los que resulta difícil darles un nombre. (...) Está situado en sus márgenes: en las orillas de los bosques, a lo largo de las carreteras y de los ríos, en los rincones más olvidados de la cultura, allí donde las máquinas no pueden llegar. Gilles Clément (2008). Manifiesto del Tercer Paisaje.

9 Sánchez Pardo, X. C., La parroquia rural, un patrimonio del que podemos aprender, La Voz de Galicia 11/05/2014. Recuperado de https:/www.lavozdegalicia.es/noticia/galicia/2014/05/11/parroquia-ruralpatrimonio-podemos-aprender/0003_201405G11P14993.htm 


\subsection{As transformacións recentes}

Os igrexarios non son alleos ós cambios na estrutura de poboación do medio rural e á renovación dos usos e das funcións que tradicionalmente soportaban, e que foron inmutables durante milenios.

Hoxe, os elementos do igrexario se transforman, e cada un deles faino de maneira diferente, tal e como explicamos a seguir:

\section{a) Cambios nas igrexas parroquiais}

En xeral, as configuracións das igrexas parroquiais non teñen variado moito, polo menos nos últimos cento cincuenta anos. Na maior parte, están en bo estado de uso e con maior ou menor fortuna, os seus elementos construtivos van sendo restaurados seguindo as técnicas tradicionais.

\section{b) Cambios nos adros}

O adro é o recinto no que se atopa a igrexa e que delimita o espazo simbólico da mesma. En orixe un murete baixo de cachotería sobre unha planta oval delimita o "sagrado", o camposanto. Nel fanse os enterramentos e nel atópase a igrexa.

A partir do século XX, o crecemento demográfico levou ás sucesivas ampliacións do cemiterio, fundamentalmente por densificación do mesmo mediante a construción de nichos en altura.

As primeiras ringleiras de nichos constrúense sobre os bordes menos principais do adro. Empeza deste xeito o fenómeno da rectificación da súa contorna, pasando progresivamente de curva a poligonal.

Neste primeiro momento, a relación visual da igrexa coa súa contorna inmediata non se ve alterada substancialmente.

Segundo vai aumentando a construción de nichos no perímetro ${ }^{10}$ do adro esa relación pódese ver completamente alterada ou mesmo deixar de existir.

Nalgúns casos, aínda que non é o habitual sucede o contrario; paralelamente á construción dun novo cemiterio veciño á igrexa, pero fóra do adro, procédese á eliminación do propio adro. Este é o caso do adro de Olveira (Dumbría), Santa María de Mogor (Mañón), ou na igrexa de Abade (Moeche).

Outro xeito de alteración dos adros o temos cando se actúa sobre o mesmo para utilizalo só como elemento de transición, e non como cemiterio e, especialmente, cando o seu espazo se fragmenta.

10 Con todo son minoritarios os casos nos que isto sucede.

O adro dáse en máis do $95 \%$ dos casos estudados. Nas áreas das Terras de Santiago e nas Zonas de Transición existe adro no $100 \%$ dos casos. Tan só na área de Ortegal o número de igrexarios con adro baixa do $95 \%$, (84,21\% de igrexas dentro do seu adro). Paralelamente tamén é aquí onde máis igrexas recentemente remodeladas, con estilos eclécticos e máis novos cemiterios se atopan. 


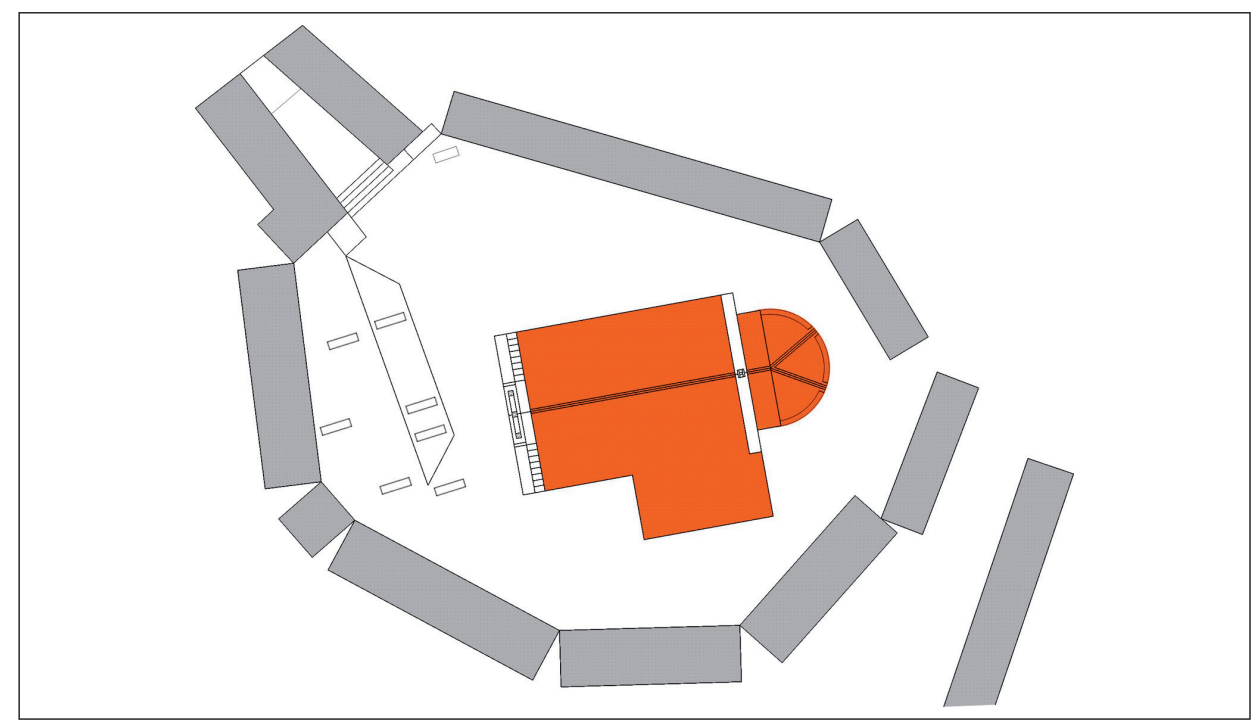

Planta da igrexa de Santa María de Cuíña en Oza Cesuras, dentro do seu adro e completamente arrodeada de nichos en altura.

\section{c) Os cambios nas casas reitorais. $O$ seu estado de abandono}

O despoboamento rural e a pérdida de practicantes nas igrexas propiciaron, na segunda metade do século XX, que progresivamente se lles fora encomendando a un mesmo párroco máis dunha parroquia. Esto fixo que pouco a pouco as reitorais tamén foran sendo abandoadas. Dun total de 380 casos nos que detectamos a presencia da reitoral, esta se atopa abandonada en 83 ocasións e en outras 75 directamente en ruína.

En moitos casos as ruínas da reitoral son derrubadas para permitir a ampliación dos cemiterios, que non deixan de ser un lucrativo negocio para as arcas parroquiais.

Outras veces as reitorais son derrubadas para deixar espazo simplemente a aparcadoiros ou ocasionais campos da festa.

Casa reitoral de Santiago de Novefontes, Touro.

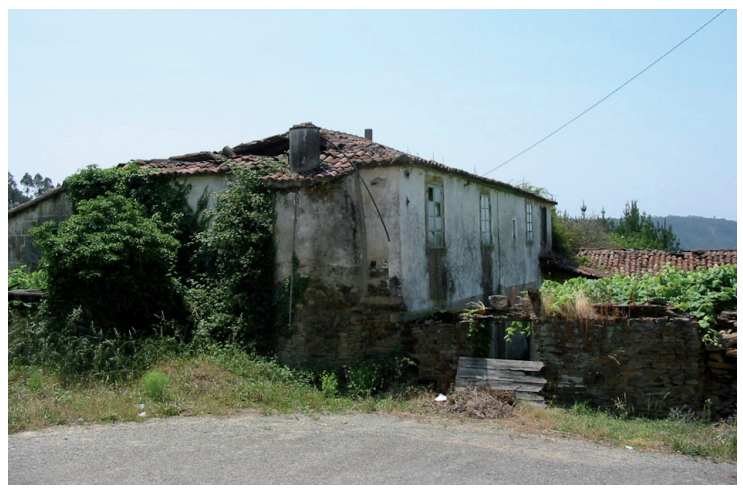




\section{d) Os cambios nas carballeiras e nos campos da festa}

Como vimos en apartados anteriores, as carballeiras do igrexario poden aparecen de dúas formas principais: ou ben como un espazo de transición diante da igrexa, con carácter especialmente simbólico, ou como campo da festa; (as veces como unha combinación das dúas).

A partir da década dos anos sesenta do século pasado, detéctase a tendencia a desaparecer moitos dos campos da festa tradicionais, e os motivos son diversos. Nalgúns casos, como en Arentía, en Boimorto, isto é consecuencia da tala da masa arbórea para aproveitar o valor económico da madeira que alí crecera. Noutros casos, a supresión de arborado e posterior asfaltado do adro, percíbese pola comunidade como un síntoma de modernidade.

Noutros casos, proponse como motivo a manobrabilidade dos vehículos como camións ou tractores que teñan que pasar polo lugar e servir á propia festa.
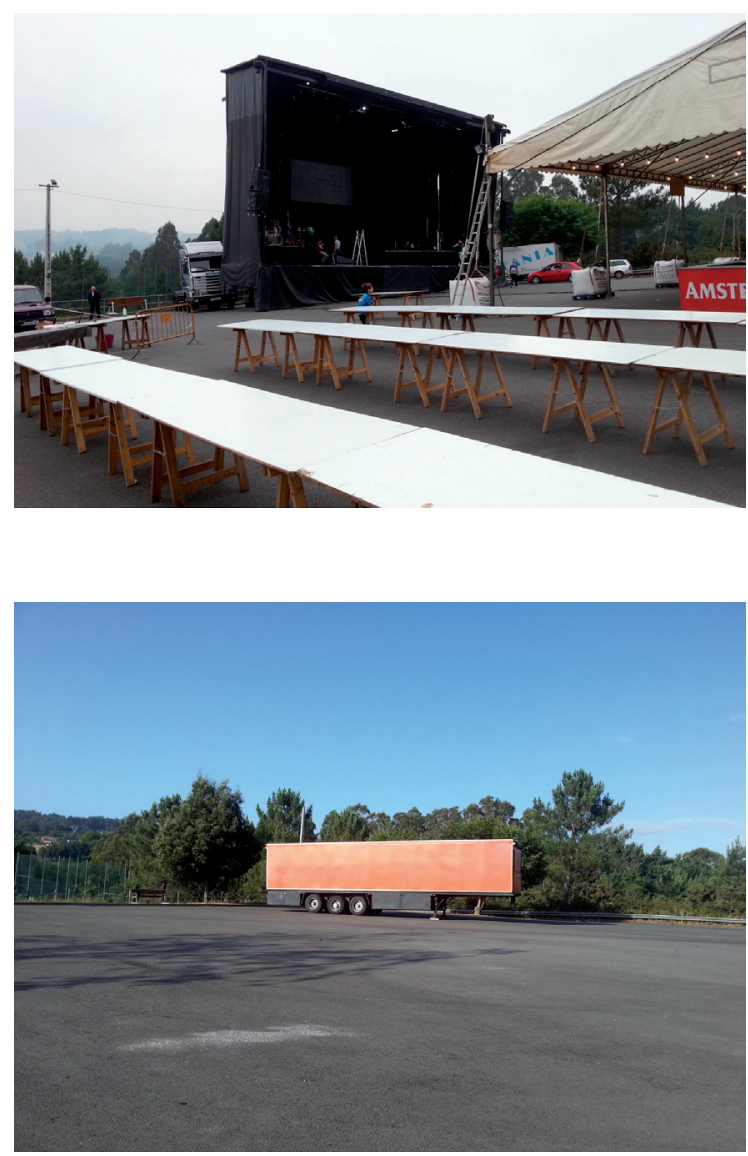

Campo da Festa de Anceis, Cambre. 
Os palcos da música tradicionais deixan de ter sentido cando as novas orquestras xa aportan os seus propios escenarios móbiles integrados en remolques de camións.

Noutras ocasións, a ampliación do cemiterio parroquial leva aparellada a substitución da carballeira dianteira por un espazo asfaltado para aparcamento de vehículos, como no caso do igrexario de Coiro na Laracha. Amparo Casares Gallego, na súa tese doutoral sobre as carballeiras en Galicia fai referencia a esta problemática (Casares, 2008).

Non faltan casos nos que os habitantes do mundo rural, sabendo que teñen perdida a partida fronte ó mundo urbano, intentan adoptar as sinais de identidade deste, e a falta doutro xeito de "urbanizar" a súa contorna máis inmediata, optan por simplemente talar o arborado e asfaltar os seus precarios espazos públicos, aínda que isto supoña a completa perda das súas calidades ambientais.

Coñecendo o carácter e a lóxica tradicional dos diferentes elementos que compoñen o igrexario, non resultaría complicado atopar solucións que conservando estes carácteres e as súas riquezas ambientais puideran adaptarse ós novos usos requiridos, ademais dos tradicionais; áreas de lecer, aparcadoiros ocasionais, lugar para festexos, xuntanza de veciños, etc.

\subsection{Análise DAFO dos igrexarios}

A proposta que se describe neste artigo nace da aplicación sistemática dunha metodoloxía DAFO ao conxunto dos casos de estudo seleccionados, analizando as súas características internas (Debilidades e Fortalezas) e a súa situación externa (Ameazas e Oportunidades) nunha matriz cadrada. Trátase esta dunha ferramenta que permite coñecer a situación xeral dunha realidade e planificar una estratexia de futuro. A través da mesma, daremos resposta as seguintes cuestións:

- Como se pode destacar cada fortaleza?

- Como se pode desfrutar de cada oportunidade?

- Como se pode defender cada debilidade ou carencia?

- Como se pode deter cada ameaza?

O obxectivo da análise DAFO é determinar as vantaxes competitivas do proxecto baixo análise e a estratexia xenérica a empregar no mesmo que máis lle conveña, en función das súas características propias e das circunstancias nas que se move.

a) As debilidades máis recorrentemente identificadas no conxunto dos igrexarios derivan de:

- A ausencia dalgún dos elementos do igrexario

- O estado de abandono ou ruína da casa reitoral

- A desconfiguración dalgún dos elementos do igrexario

- O impacto producido por edificacións non tradicionais e non congruentes tipoloxicamente co medio 
- A transformación da compoñente vexetal (abandono da agricultura, avance dos monocultivos forestais de especies foráneas, abandono dos pastos, etc.)

- O viario e o mobiliario accesorio non están debidamente coidados ou son de baixa calidade.

b) En xeral as ameazas veñen derivadas dos cambios no sistema de poboamento, ben pola perda de habitantes ou ben pola proximidade dos fenómenos urbanos e a presión urbanística que esta comporta. En todo caso, sempre se deriva desto o abandono das actividades agrarias tradicionais, dando lugar nun caso á aparición de contornas naturais non autóctonas e, no outro, á destrución da paisaxe cultural.

Por outra banda, debe destacarse a alta frecuencia con que o planeamento urbanístico resulta paradoxalmente unha ameza, ben sexa pola insensibilidade no tratamento da singularidade do igrexario como na indisciplina urbanística.

Aínda que con desigual incidencia segundo zonas, constitúe unha ameaza en xeral o crecemento edificatorio, coa extensión das tramas urbanas sobre a paisaxe cultural preexistente.

c) Como indiscutible fortaleza, destacamos a imaxe de alta calidade visual dos conxuntos dos igrexarios, que en xeral sempre é ben recoñecida pola veciñanza. Nas súas contornas é doado rastrexar as pegadas deixadas pola paisaxe cultural, e son abondosas as mostras de arquitectura vernácula. Mesmo cando estas se atopen alteradas, vese factible a súa mellora.

Os elementos do igrexario están na súa maioría (igrexas, cruceiros e mesmo reitorais) inventariadas como parte do patrimonio cultural. Os conceptos relacionados coa parroquia son socialmente asociados co igrexario como elemento de referencia da mesma.

Malia os graves problemas que atravesa o sector agro gandeiro, aínda existen evidencias da súa actividade no conxunto das áreas estudadas.

Aínda que nun estado un tanto incipiente, tamén existen evidencias de existencia de actividades turísticas relacionadas coa natureza e o patrimonio cultural.

d) No que se refire ás oportunidades, a rede de igrexarios constitúe un conxunto de espazos colectivos de calidade, cunha óptima aptitude para a estruturación do territorio na súa escala máis elemental e aportando unha clara referencia como imaxe identitaria aos residentes. Os igrexarios aséntanse en xeral nunha contorna natural e paisaxística de alto valor e autóctona. Unha gran parte dos mesmos atópase dun ou outro xeito nunha certa veciñanza aos camiños de Santiago e son moitos, ademais, os que se atopan preto de zonas da Rede Natura ou outras de semellante efecto.

As paisaxes culturais das que os igrexarios son fitos fundamentais, son soporte preferente para a agricultura e gandería sustentables e ecolóxicas. A demanda por estes produtos é crecente, como tamén o é dun turismo sustentable, relacionado co patrimonio e a natureza. Todo isto ten que redundar forzosamente no aumento do nivel de ocio e de renda dos habitantes das zonas sobre as que os igrexarios se asentan. 


\section{DISCUSIÓN DOS RESULTADOS}

A sistemática lectura da vasta área ocupada polas 750 parroquias estudadas permítenos propor unha definición actualizada do que é a paisaxe cultural nesta rexión de Galicia que, aínda presentando características que visualmente a emparentan coa ruralidade, dende outros puntos de vista xa deixou de ser un mundo tradicional agrario.

A xestión do territorio non pode darse sobre tabula rasa por canto o territorio está organizado sobre unha malla, secularmente tecida polo traballo de incontables xeracións de homes e mulleres, que armaron unha racional rede de fitos territoriais (nas que os igrexarios constitúen os seus nódulos referenciais desde o punto de vista histórico e cultural) que hoxe continúan -malia cambios e axustes- vixentes.

Debe considerarse que aproveitar a potencialidade desta estrutura básica de ocupación dun xeito natural, "coherente coa organización topográfica e ecolóxica do territorio" en palabras de Dalda Escudero (2008) é unha oportunidade e non como unha "distorsión" ante os novos modelos de poboamento posibles.

$\mathrm{Na}$ inadecuación entre as preexistencias e os modelos superpostos que se veñen producindo radica grande parte da problemática da urbanística contemporánea, responsable da aparición de conflictos, maioritariamente nos espazos máis vitais, que a cidadanía, a falta dunha diagnóse que se fai esperar, chama "feísmo".

A paisaxe cultural ten moitas oportunidades para seren aproveitada como base dunha ocupación sostible do medio. O problema é que primeiro ten que ser entendida e, desgraciadamente, ó longo da segunda metade do pasado século, xeralmente non foi así.

A paisaxe cultural e o sistema de poboamento tradicional que sobre o mesmo se asenta son nocións indisolubles e directamente relacionadas unha coa outra. O igrexario representa o núcleo histórico, cultural e identitario neste sistema que ten como célula elemental a parroquia. A pervivencia da estrutura dos igrexarios, é fundamental na preservación da identidade do territorio. Esta identidade debemos entendela segundo os criterios internacionais e, en especial, a Carta de Cracovia do ano 2000 (Principios para a conservación e restauración do patrimonio construído) como a referencia común de valores presentes xerados na esfera dunha comunidade e os valores pasados identificados na autenticidade dos seus elementos patrimoniais.

Todos estes factores debemos entendelos tamén inseridos nos Obxectivos ${ }^{11}$ de Desenvolvemento Sostible do Programa das Nacións Unidas (ODS) para o Desenvolvemento, e de xeito máis particular nalgúns deles, concretamente:

ODS 8. Fomentar o crecemento económico sostido, inclusivo e sustentable, o emprego pleno e produtivo, e o traballo decente para todos

ODS 11. Lograr que as cidades e os asentamentos humanos sexan inclusivos, seguros, resilientes e sustentables.

11 Os Obxectivos de Desenvolvemento Sostible do Programa das Nacións Unidas (ODS) foron aprobados en decembro de 2015 pola Asemblea Xeral das Nacións Unidas. 


\section{CONCLUSIÓNS}

A análise sistemática dos 750 igrexarios referidos nos permite obter conclusións sobre ás pezas en si como elementos pertencentes ao acervo patrimonial das xentes, como elementos territoriais e como vector de potencialidades a explorar.

a) O igrexario como peza patrimonial

- Os igrexarios forman unha rede sobre o territorio da área estudada que coincide coa estrutura parroquial.

- Os igrexarios na súa inmensa maioría aínda son espazos visitados con asiduidade, relacionándose co seu uso relixioso (en menor medida), social e funerario (especialmente).

- A igrexa parroquial é o elemento que se atopa en mellores condicións e menos alterado con relación ós patróns tradicionais de todos os que integran o igrexario, en tanto as casas reitorais, as compoñentes do igrexario que con maior frecuencia mostran un peor estado de conservación e en maior medida presentan estado de abandono ou de transformación atipolóxica.

b) O igrexario como peza territorial

- A veciñanza en liñas xerais aínda senten a súa pertenza á parroquia no seu aspecto social.

- Os elementos do igrexario son percibidos como as sinais físicas da identidade da parroquia.

c) O igrexario como vector de potencialidades a explorar.

Os igrexarios e os seus espazos vinculados teñen funcionado como polos da vida social das comunidades do medio rural dende a Idade Media. A gran maioría deles atópanse nas súas localizacións orixinais desde esas datas e, nalgúns casos, mesmo son anteriores. Son numerosos os casos nos que os seus diferentes elementos forman conxuntos de gran calidade ambiental, urbanística e mesmo arquitectónica.

A localización dos igrexarios adoita ter unha posición centrada dentro dos límites da parroquia ou, polo menos, de certa equidistancia cos seus núcleos, e isto contribúe a facelos propicios para acoller nos seus elementos baleiros, ou mediante novas pezas ó seu redor, os equipamentos da parroquia.

\section{ESTABLECEMENTO DO MÉTODO A EMPREGAR NAS INTERVENCIÓNS NOS IGREXARIOS}

Considerando que o medio rural ten na rede de igrexarios a estrutura consolidada sobre a que seguir producindo a xestión do territorio no sucesivo, aquí aventuramos unha proposta metodolóxica que permita a referida construción. Utilizaranse como criterios os prescritos nas diferentes cartas que se refiren aos criterios de intervención o medio rural 
ou no patrimonio cultural, pero moi especialmente os criterios establecidos nos ODSS do planeta. O método que propomos basease en catro estratexias fundamentais:

APROVEITAR as potencialidades do conxunto do igrexario.

CONSOLIDAR as fortalezas dos seus diferentes elementos.

CORRIXIR as debilidades dos diferentes elementos do igrexario e do seu conxunto.

RECUPERAR os elementos que se perderan ou están a piques de facelo.

De modo xeral:

APROVEITAREMOS o conxunto dos elementos do igrexario como referencias identitarias da parroquia; símbolos do presente e do pasado da mesma. Aproveitaremos tamén a centralidade dentro da parroquia do igrexario e dos seus espazos públicos vinculados, para utilizalos como soporte das novas dotacións e equipamentos da mesma.

CONSOLIDAREMOS os elementos tradicionais do igrexario atendendo á súa lóxica orixinaria sobre o terreo; poremos atención ás delimitacións dos adros das igrexas como elementos contedores dun ámbito simbólico no que as mesmas se atopan.

Atenderemos ós emprazamentos dos cruceiros, entendendo que os mesmos son antes que outra cousa marcas sobre o territorio. Evitaremos sempre que sexa posible o seu traslado desde os emprazamentos orixinais e tentaremos, cando haxa posibilidade, de devolver estes ás súas localizacións anteriores, cando se teña constancia do seu traslado.

Poremos atención ós espazos públicos inmediatos ó igrexario; consolidaremos as carballeiras do igrexario cando as haxa intentando conservar no seu sitio os seus elementos, reforzando o seu papel de equipamento coa introdución de mobiliario urbano adecuado ás características do conxunto e impedindo na medida do posible o seu uso como aparcadoiro.

CORRIXIREMOS aqueles aspectos que teñan deteriorado a imaxe e a simboloxía dos elementos do igrexario. Son habituais os impactos producidos polas diferentes ampliacións dos cemiterios parroquiais, especialmente aquelas que se producen mediante a consolidación en altura do perímetro do adro, mediante a construción de ringleiras de nichos. Aparte da interferencia na relación visual entre o camposanto, a igrexa e o resto da súa contorna, é habitual que as traseiras destes nichos estean completamente descoidadas, ofrecendo unha imaxe externa dos elementos máis principais do igrexario, non axeitada en absoluto. Intentaremos na medida do posible manter a relación visual entre os elementos do igrexario e a súa contorna inmediata. Aplicaremos medidas correctivas aos paramentos traseiros dos bloques de nichos que teñan un maior impacto visual, mediante o tratamento dos seus paramentos con materiais que teñan máis relación coa contorna ou con elementos vexetais.

Trataremos os pavimentos das zonas inmediatas ós igrexarios tentando dar por unha banda unha imaxe de unidade ó conxunto, consolidar os percorridos peonís, darlle maior coherencia na utilización dos materiais e, por outra, mitigar o impacto do tráfico rodado na contorna inmediata do igrexario.

RECUPERAREMOS aqueles elementos do igrexario que teñan caído en desuso, buscando para os mesmos novos usos e funcións cando as antigas xa non teñan sentido ou precisen ser complementados. 


\section{BIBLIOGRAFÍA}

Arias Vilas, F. (1992): A romanización de Galicia. Vigo, Ed. A Nosa Terra.

Ballesteros Arias, P. (2002): "A paisaxe agraria de Elviña: os elementos e as formas" en Cadernos de Arqueoloxía e Patrimonio $n^{\circ}$ 15, pp. 1-52.

Ballesteros Arias, P. (2010): "La Arqueología rural y la construcción de un paisaje agrario medieval: el caso de Galicia”, en H. Kirchner (ed.): Por una arqueología agraria. Perspectivas de investigación sobre espacios de cultivo en las sociedades medievales hispánicas. Oxford, Archeopress, BAR International Series 2062, pp. 25-39

Barreiro Fernández, X. R. (2009): “A reforma parroquial de 1867: A diocese de Santiago de Compostela" en A parroquia en Galicia, pasado, presente e futuro. Santiago de Compostela, Xunta de Galicia.

Bas López, B. (2002): As construcións populares: un tema de etnografía en Galicia. A Coruña, Edicións do Castro.

Bouhier, A. (1979): La Galice. Essai géographique d'analyse et d'interprétation d'un vieux complexe agraire, I- II, La Roche-Sur-Yon.

Cabana Iglesia, A. (2008): "Lo que queda de las agras: La evolución del paisaje agrario en Galicia. El caso de la comarca lucense de Terra Cha" en Actas do XII Congreso Agrario. Córdoba 2008

Carballo Arceo, X. (1990): "Los castros de cuenca media del río Ulla y sus relaciones con el medio físico" en Trabajos de Prehistoria, vol. 47. Madrid; pp. 161-199.

Casares Gallego, A. (2008): As carballeiras en Galicia. Un patrimonio para conservarmos. Santiago de Compostela. Xunta de Galicia.

Clément, G. (2004): Manifeste du Tiers paysage. Paris, Éditions Sujet/Objet.

Currás Refojos B. (2014): "Mapa de usos potenciales de la tierra de Galicia. Una perspectiva arqueológica”, en Trabajos de Prehistoria 71, $n .^{\circ} 1$, pp. 23-41

Dalda Escudero J. L. García Docampo, M., González Harguindey, J., (2006): Cidade difusa en Galicia, Santiago de Compostela, Xunta de Galicia.

D’Emilio, J. (1996): “Los documentos medievales como fuentes para el estudio de las parroquias e iglesias gallegas: El distrito de Monte de Meda (Lugo)" en Cuadernos de Estudios Gallegos, Tomo XLIII, Fascículo 108.

Fariña Jamardo, X. (1975): La parroquia rural en Galicia. Madrid, Instituto de Estudios de Administración Local.

Fariña Tojo, J. (1980): Los asentamientos rurales en Galicia. Madrid, Instituto de Estudios de Administración Local.

García Fernández, J. (1975): Organización del espacio y economía rural en la España Atlántica. Madrid, Siglo XXI editores.

Geddes, P. (1915): Cities in evolution Londres, Williams \& Norgate.

George, P. (1963): Précis de Géographie Rurale. Paris, Presses Universitaires de France.

Lema Suárez, X. M. (1977): Bamiro, un estudio do habitat rural galego. Santiago de Compostela, Colexio Oficial de Arquitectos de Galicia. 
Llano Cabado, P. de (1981): Arquitectura popular en Galicia. A Coruña, COAG.

O'Flanagan, P. (1995): Xeografía histórica de Galicia. Vigo, Edicións Xerais de Galicia.

Pallares Méndez, M. C. (1978): "El poblamiento rural gallego en la Edad Media” en Revista Obradoiro $n^{\circ} 2$, pp. 3-14

Pazo Labrador, A. J., Moragón Arias, M. P. (2010): “Cartografía del despoblamiento en Galicia a escala parroquial. La Galicia Occidental" en Revista de Investigación en Educación, $n^{o}$ 8, pp. 39-54.

Precedo Ledo, A. (1998): Geografía humana de Galicia. Barcelona, Oikos-Tau Ed.

Sampaio, A. (1895): “As Vilas do Norte de Portugal”, na Revista de Sciências Naturaes e Sociaes, Porto, 1895.

Sánchez Pardo, J. C. (2007): "Una propuesta de análisis geohistórico de las aldeas tradicionales gallegas" en Cuadernos de Estudios Gallegos, Liv N ${ }^{o}$ 120, pp. 103-134

Sánchez Pardo, J. C. (2009): "Sobre los orígenes y evolución de las primeras iglesias rurales en la alta edad media: el caso de Terra de Celanova (Ourense)" en Revista Aqvae Flaviae $n^{\circ} 41$, pp. 433-448.

Sánchez-Pardo, J. C. (2010).:"Las iglesias rurales y su papel en la articulación territorial de la Galicia medieval (SS. VI-XIII): Un caso de estudio" en Mélanges de la Casa de Velázquez, pp. 149-170. 